\title{
A Pedagogical Model for CyberParks
}

\author{
Philip Bonanno ${ }^{1(\Phi)}$, Michal Klichowski ${ }^{2}\left(\mathbb{0}\right.$, and Penelope Lister $^{1}$ \\ ${ }^{1}$ Department of Leadership for Learning and Innovation, Faculty of Education, \\ University of Malta, Msida, Malta \\ \{philip. bonanno, penelope.1ister.16\}@um.edu.mt \\ ${ }^{2}$ Faculty of Educational Studies, Adam Mickiewicz University in Poznan, \\ Poznan, Poland \\ klichowski.michal@gmail.com
}

\begin{abstract}
This chapter discusses the recent conceptual developments about CyberParks and their educational potential. Key learning characteristics and pedagogical principles will be identified through a review of learning theories and studies from cognitive neuroscience. Relevant pedagogical models are reviewed to develop one that describes learning in CyberParks, which will be used to design and evaluate learning in such context. An innovative connectivistinspired process-oriented pedagogical model is proposed to serve as a signpost in the process of developing adaptive expertise through which new pedagogies and innovative uses of CyberParks address the evolving needs of citizens.
\end{abstract}

Keywords: Pedagogy $\cdot$ Smart city learning $\cdot$ Design for learning $\cdot$

Connectivism $\cdot$ Cognitive neuroscience

\section{Introduction}

A cyberpark - the meditated public open space - can be considered as a hybrid urban learning space that combines natural with man-made features, the physical with the digital, the local with the global, formal with informal learning. Citizens use it for recreation and entertainment, to socialise, pursue healthy lifestyles, learn about themselves and their surroundings and participate in the development and use of their hybrid habitat (Klichowski 2017). Digital technologies and communication systems mediate, enhance and transform people's interaction in a cyberpark. The emphasis in literature about cyberparks and smart cities is more on the role of citizen-users and the enhancement of their quality of life rather than on the role played by physical and technological factors. Thomas et al. (2016) epitomises this in the concept of smart cities as place, people and purpose.

\section{The Educational Potential of CyberParks}

Cyberpark is smart physical learning environments exploiting the affordances of digital, context-aware and adaptive devices that promote better and faster learning through ubiquitous digital connectivity (Isaksson et al. 2017; Klichowski 2017). This enables 
learners to connect in context-aware scenarios to a wider network of knowledge, experts and learning communities via their adaptive devices. For Hwang (2014) a smart learning environment, besides enabling learners to access digital resources and interact with learning systems in any place and at any time, actively provides the necessary learning guidance, supportive tools or learning suggestions. Buchem and PerezSanagustin (2013) propose four modes of learning (seamless learning, crowd learning, geo-learning and citizen inquiry) that emerge in such contexts manifesting users' interaction with the natural, historical, cultural, architectural and digital dimensions of the space. For Sharples et al. (2012) seamless learning is evident when a person experiences a continuity of learning across a combination of locations, times, technologies and social settings. Gros (2016) characterises learning in technology-enhanced environments (like in a cyberpark) as fundamentally personal, social, distributed, ubiquitous, flexible, dynamic and complex in nature. She states that one of the most important features of smart learning is that the data used serves as feedback for the learner to support personalised learning.

Hybrid environments like a cyberpark may trigger deep learning that change an individual's competence profile and epistemological conceptions. Interactivity extends the zone of possibilities providing new focussed learning instances (Cook et al. 2015). Buchem and Perez-Sanagustin (2013) contend that, when mediated through mobile technologies and locative media, the surrounding physical and the digital environment can be dynamically merged into augmented, ad-hoc personal learning environments. By interacting with these hybrid environments learners develop $21^{\text {st }}$ century skills including efficient and effective access of information and knowledge, inquiry/ problem-solving, creative, collaborative and communicative competences, and the ability to be innovative in using the surrounding habitat in culturally sensitive, globally aware and ethically responsible ways. Through networked technologies citizen-learners develop new interactional patterns with the various aspects of hybridity.

Cyberparks can challenge people to extend their learning boundaries through acquisition of new knowledge and skills, by sharing their understanding and by contributing to the distributed knowledge and networked experience (Klichowski 2017). The more citizens learn about technology and learn through technology the more empowered they become to interact with the surrounding environment. The situation is complex as it merges different epistemologies within one learning instance or calls on relevant epistemologies for different instances of learning. Consequently, different theories of learning serve as conceptual lenses through which interactions cyberpark can be analysed to identify the underlying learning principles and conditions.

\section{Theories of Learning}

Learning in a cyberpark is a composite experience involving intra-individual cognitive, affective and conative interactions together with inter-individual, networked, interactional processes. Anderson (2010) distinguishes between pre-net theories (developed before the event of the internet) and net-aware theories (characterising contexts rich in information and communication systems). Learning experience in cyberparks links to different theories according to the situation and conditions. 


\subsection{Pre-net Learner-Centric Theories}

Behaviourist, cognitive, neurocognitive and socio-cultural theoretical perspectives describe manifested internal processes and external behaviours. Yet, while behaviourist pedagogies deliberately go no further than observable inputs and outputs, cognitivist approaches take into account the mental models and internal processes, building on a richer psychological understanding of learning and how it occurs (Dron and Anderson 2014). Mayes and de Freitas (2004), as well as Beetham and Sharpe (2007), describe three theoretical dimensions of learning - the associative, the cognitive and the situative. Learning in cyberparks may include aspects of the associative approach, for example when following prescribed learning activities to learn concepts or skills initially through basic stimulus-response conditioning and later by associating concepts in a chain of reasoning, or associating steps in a chain of activity to build a composite skill. The main focus is on the alignment of learning objectives, instructional strategy and assessment. This approach to learning is not concerned with how concepts or skills are represented internally, but how these are manifested in external behaviours and observable learning.

In contrast, cognitive approaches emphasise modelling of the processes of interpreting and constructing meaning. Knowledge acquisition is the outcome of interactions between new experiences and the relevant memory structures. The key cognitive challenge is to build a framework for understanding rather than behaviouristic strengthening of associations. It is also more authentic, contextual and social in nature, as these aspects are perceived more appropriate for equipping learners with the skills, they will need to participate in a constantly changing societal context (Conole 2014). Learning in cyberparks may have a constructivist orientation promoting understanding through active exploration of the hybrid environment. It can also involve constructionist activities when learners are engaged in creating something for others to see (Papert 1993). Learning by designing may result in effective participatory learning approaches and of embracing ways in which the web-service-based environment offers potential for learning (Beetham 2013).

Social constructivist learning results from achieving understanding through dialogue and collaboration with peer learners, tutors and experts who play a key role in developing a shared understanding of the task and provide feedback and support on the learner's activities and reflections, enabling learners to reach beyond what they are individually capable of learning. Situated learning emphasises social interaction within a community of practice through which one develops competences related to a particular role within the community progressing from novice to expert through observation, reflection, mentorship, and legitimate peripheral participation in community activities.

Cognitive neuroscience (in both behavioural and neuroimaging paradigms, see Klichowski and Kroliczak 2017) provides another learner-centric framework. Klichowski and Patricio (2017) show that learning in cyberparks combines two types of cerebral operations: motor and cognitive control. Many times, this involves learning 
with digital tools while on the move (Klichowski et al. 2015; Klichowski and Smaniotto Costa 2015). This cognitive-motor interaction requires an appropriate allocation of cognitive and motor resources for each operation. Figure 1 shows that the human brain does not cope well with this situation, which leads to an overload of central resources, and thus to destabilization of the course of cognitive and motor processes, the consequence of which is the weakening of both cognitive and motor tasks. Thus, using a smartphone while walking increases the risk of falling; performing arithmetic operations while driving reduces the accuracy of the result (Yamada et al. 2011). This effect is called dual-task cost (Takeuchi et al. 2016) and its implication for learning in cyberparks is that one should use technology for learning while stationary (sitting) but definitely not while walking. Experiment realised in a cyberpark by Klichowski (2017) use the two behavioural paradigms and the mobile electroencephalography method confirmed this. Thus, the idea of smart and immersive learning, in a sense, has to be revised.

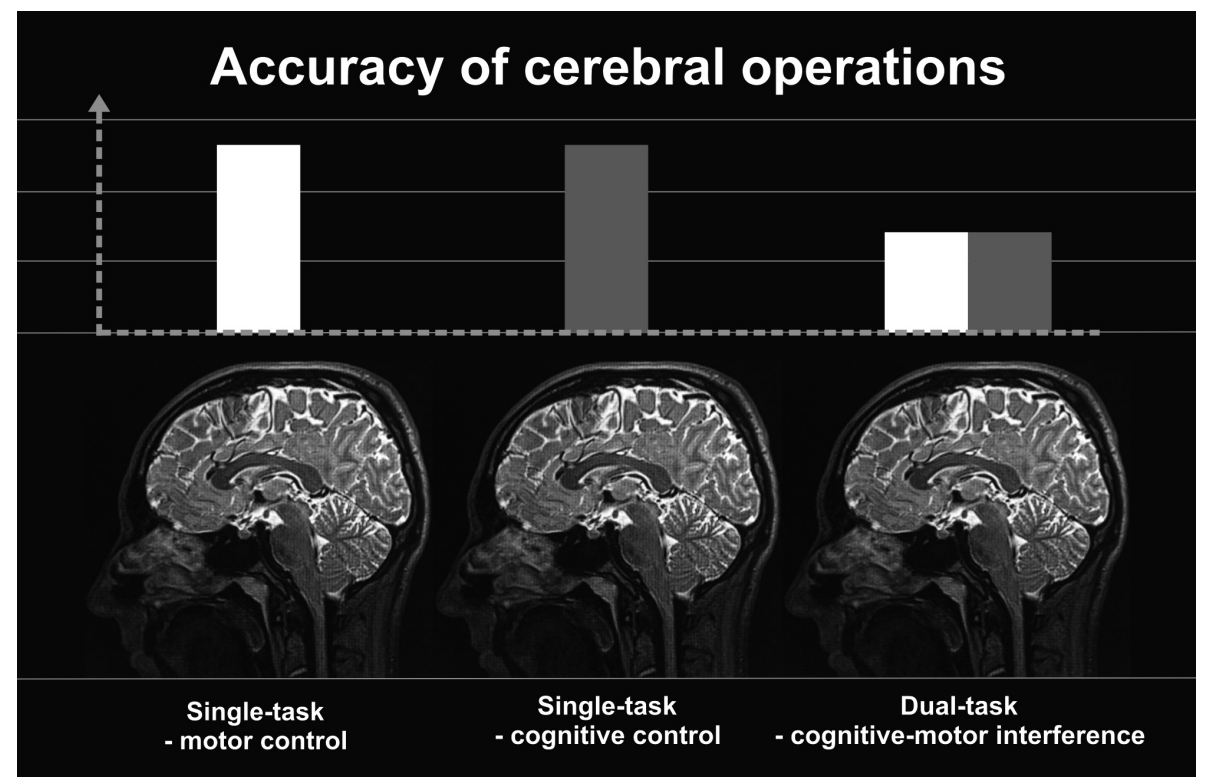

Fig. 1. The dual-task cost theory. The best cognitive or motor results are obtained when separating these processes. Their interaction weakens the results of both. Source: own work based on Pothier et al. (2014) and Yuan et al. (2016)

\subsection{Post-net Networked Systems Theories}

Gros et al. (2016) give three major categories of post-net networked systems theories: theories focused (1) on the network, (2) on social-personal interaction and (3) on the design of the network. The first category includes networked learning, connectivism and actor network theory (ANT). For Goodyear et al. (2004) networked learning involves the use of digital technologies to promote connections between learner-to-learner, 
learner-to-tutors and learning community-to-its learning resources. Learning and knowledge construction is located in the connections and interactions between learners, teachers and resources, and seen as emerging from critical dialogue and enquiry. Such a perspective promotes learning as a social, relational phenomenon, and view knowledge and identity as constructed through interaction and dialogue.

In line with this theory, connectivism considers knowledge as a flow through a network of humans and non-humans (artefacts) comprising connections between nodes that can be individuals, groups, systems, fields, ideas, resources or communities (Siemens 2005). Downes (2006) considers knowledge residing not only in the mind of an individual but is also distributed across an information network or multiple individuals. Knowledge and learning can be defined in terms of connections: know where and know who are more important today than know what and know how (Siemens 2005). The connections that enable us to learn are more important than our current state of knowing. The claim that knowledge is held in the network and that the learning is the network is one of the most debated points of connectivism. Having transient knowledge residing in technical networks and learning externalised into human mediated distributed networks where it takes place and is, and not being restricted to a single individual to be internalised, contrast with the central tenets of previous learning theories. For Downes (2007) knowledge is literally the set of connections formed by actions and experience. It may consist in part of linguistic structures, but other digital media may play an important role in developing knowledge of a less linguistic, more affective and intuitive nature. Thus, learners need to develop skills in digital, information and media literacy, and critical thinking, alongside their understanding of how networks work.

Making no distinction in approach between the social, the natural and the technological, ANT proposes a socio-technical account that explores ways heterogeneous networks, of both human and non-human actors, are constructed and maintained, and focuses on tracing the transformation of these heterogeneous networks (Latour 2005). An actor is anything granted to be the source of an action, and is also a simplified network. There is no difference in the ability of technology, humans, animals or other non-humans to act. While it is possible to render social connections traceable in simple knowledge systems, there is no means to trace these or follow the actors or their actions in complex knowledge systems because these are uncertain, unexpected and often hidden and their connections are varied, ubiquitous and open (Latour 2005). For Gros et al. (2016) the main problem of this approach is that it reduces all actors into black boxes ignoring internal actions such as reflecting, self-criticizing and detecting/correcting errors, providing an incomplete, quasi-behaviourist explanation to the intra-individual and external interactions within hybrid environments like CyberParks.

The same authors discuss theories that focus on social-personal interaction considering learners who navigate through hybrid environments and through their own personal networks. Learning in cyberparks can be considered as part of the overarching lifelong and life wide self-determined learning, an approach in which learners take control of their own learning through self-management, self-monitoring and extension of their own learning (Tan et al. 2011). Heutagogy, another theoretical framework under the social-personal interaction category, is defined as the study of selfdetermined learning (Hase and Kenyon 2007) and developed as an extension to 
andragogy, or self-directed learning (Blaschke 2012). Compared to andragogy, heutagogy expands further upon the role of human agency in the learning process considering the learner as the key agent in learning (Hase and Kenyon 2007). Key concepts in heutagogy are:

- The instructor facilitates learning by providing guidance and resources, fully relinquishing ownership of the learning path and process to the learner, who negotiates the content and modality of learning.

- Involves double-loop learning and self-reflection. Learners consider the problem, the resulting action and outcomes in addition to reflecting upon the problem-solving process and how it influences learner's own beliefs and actions.

- There is a progression from andragogy to heutagogy, with learners likewise progressing in maturity and autonomy (Canning 2010). Being more self-directed, mature learners require less instructor control and course structure; less mature learners require more instructor guidance and course scaffolding (Canning and Callan 2010).

- Web 2.0 design supports a heutagogical approach by allowing learners to direct and determine their learning path and by enabling them to take an active role in their individual learning.

The last category of post-net networked systems proposed by (Gros et al. 2016) are theories focused on the affordances or design of the network. Learning as a network (LaaN) theory represents a theoretical framework for personal learning environment (PLE) models that is an emerging concept and a new vision of learning inspired by constructivist and connectivist learning models. It puts the learner at the centre and provides more autonomy and control over the learning experience (Klichowski 2017). LaaN views knowledge as a personal network and as inherently social. Learners need to be good knowledge networkers as well as good double-loop learners who can create and maintain external networks by identifying, integrating and elaborating knowledge nodes that can help to achieve better results, in a specific learning context. As a doubleloop learner, one develops the ability to detect and correct errors and eventually change the theories-in-use according to the new setting.

This brief review of relevant learning theories points to key pedagogical factors that are at play in technology-enhanced learning environments. The following pedagogical model combines these principles for describing, designing and assessing learning in cyberparks.

\section{Toward a Pedagogical Model for CyberParks}

Bonanno $(2011$; 2014) uses a process-oriented model based on dimensions and levels of interactions for designing ubiquitous learning and learning within social networks. The dimensions of interactions are subject-content, technology, data networks and community. For learning in Cyberparks, this model can be extended by including the physical environment as another dimension. 
Considering knowledge as distributed across networks of connections, Wang et al. (2014) developed a pedagogical model based on the characteristics and principles of interaction in complex connectivist learning contexts identifying three categories of connectivist learning activities: (1) personal knowledge acquisition from networked distributed knowledge, (2) social networked learning by building communities that form a network for knowledge sharing and connection, and (3) complex connectivist learning where learners prompt connection building and network formulation by contributing to distributed knowledge, to decision-making related to complex problems, and to the development of technological and pedagogical innovations.

Researchers about online learning identified dimensions of interactions according to technological affordances including student-teacher, student-student, studentcontent, student-interface, teacher-teacher, teacher-content and content-content interactions (Moore 1989; Hillman et al. 1994; Anderson and Garrison 1998). Through their social constructivist orientation, Web 2.0 and social technologies promote various forms of interpersonal interaction comprising group-content, group-group, learnergroup, and teacher-group (Dron 2007), as well learner-content, learner-technology and learner-community (Bonanno 2011; 2014). Connectivist pedagogy, with its emphasis on the development and nurturing of networks as a major component of learning, extended the interaction possibilities to include groups, sets and networks (Dron and Anderson 2014. Besides dimensions researchers considered also levels of interaction such as learner-self, learner-resource (human and nonhuman) and a meta level learnerinstruction interaction which guides the previous two types (Hirumi 2002; operation interaction, information interaction, and concept interaction, from simple to complex and concrete to abstract (Chen 2004; learner-content, learner-interface, learner-support, learner-learner, and learner-context (Ally 2004); pedagogical levels of acquisition, participation and contribution in relation to novice, experienced and expert competence levels in the domain, technology and community dimensions (Bonanno 2011; 2014).

Building on this literature about dimensions and levels of interaction researchers developed pedagogical models to facilitate the design, assessment and evaluation of learning in technology-enhanced contexts. Chen (2004) developed the hierarchical model for instructional interaction (HMII) in a distance-learning context, based on Laurillard's conversation framework. According to this model learners that shift from concrete to abstract and from low to high levels manifest three levels of interactions. The most concrete level, on which the other levels depend, is operation interaction, in which the learner operates different media and is interacting with the media interface.

The second level is information interaction, which includes learner-teacher, learnerlearner, and learner-content interactions. In connectivist, networked environments characterised by fluid, complex and emerging knowledge, learners have to orientate themselves to filter, integrate, and extract information so as to make it coherent and understandable. Siemens (2011) proposed two means of information interaction and orientation in such complex online learning environments: wayfinding (orienting oneself spatially through the use of symbols, landmarks and environmental cues) and sensemaking (responding to uncertainty, complex topics or in changing settings).

The third level of HMII concept interaction is the most abstract and includes intraindividual cognitive and affective interactions that form neural networks. It stimulates the deepest cognitive engagement characterised by knowledge creation and growth 
(Downes 2006; 2007). It includes creation of new learning artefacts individually or collaboratively and it is combined with learner-content interaction, but in collaborative learning environments (Wang et al. 2014).

These three levels of interaction can occur simultaneously and recursively, and are hierarchical with the operation interaction serving as the foundation of information interaction, while information interaction is the foundation of concept interaction. For (Chen 2004) the higher the level, the more critical it is to the achievement of learning objectives so that only concept interaction leads to meaningful learning. Merging Downes $(2006 ; 2007)$ concept of innovation interaction with Bloom's revised taxonomy (Anderson et al. 2000) that proceeds from remembering to understanding, applying, analysing, evaluating, and creating as cognitive processes, Wang et al. (2014) superimpose four interaction levels onto the HMII. These are operation, wayfinding, sensemaking and innovation interaction. In operation interaction learners merely practice and remember how to operate various media to build their own learning spaces. In wayfinding interaction, learners have to master the ways to navigate in a complex information environment and connect with different human and nonhuman resources, thus reaching higher levels of understanding, applying and evaluating information and connection formed in this process. Sensemaking is a pattern recognition process, mainly involving applying, analysing and evaluating information. Innovation interaction focuses on the expression of ideas, models or theory by artefact creation and innovation to enhance and build new social, technological and informational connections. This engages learners at the deepest, creation level of Bloom's taxonomy.

Another process-oriented pedagogical model proposed by Bonanno $(2011 ; 2014)$ integrates interactions along three dimensions (domain, technology and community) within three pedagogical levels of interaction (acquisition, participation and contribution). Table 1 show how this can be represented.

Table 1. Process-oriented pedagogical model proposed by Bonanno $(2011 ; 2014)$

\begin{tabular}{l|l|l|l}
\hline \multirow{2}{*}{ Levels } & \multicolumn{3}{|c}{ Dimensions } \\
\cline { 2 - 4 } & Domain & Technology & Community \\
\hline Acquisition & & & \\
Participation & & & \\
Contribution & & & \\
\hline
\end{tabular}

The acquisition level is similar to Wang's et al. (2014) operation interaction dealing with basic interactional skills in the domain (information categorisation), surface structure of digital tools and interpersonal interactional skills. The participation level is linked to the information interaction level comprising wayfinding and sensemaking within the domain and the learning community. The contribution level is identical to concept interaction and innovation interaction as it deals with learners' creations within the three domains. 
Developed to consider interactions in on-line learning environments these two models do not capture all the dimensions of interactions evident in Cyberparks. Interactions of the different agents (persons, technology or data) with the physical environment are not considered. This shortcoming is addressed by including a fourth dimension - the physical environment. Another dimension (data) is being added considering Cyberparks as smart learning environments characterised by the utilisation and generation of data. To achieve more comprehensive coverage of the possible interactions in a CyberPark, the two models are merged into one, which is depicted in Table 2.

Table 2. A pedagogical model for CyberParks

\begin{tabular}{|c|c|c|c|c|c|}
\hline \multirow[t]{2}{*}{ Levels } & \multicolumn{5}{|l|}{ Dimensions } \\
\hline & $\begin{array}{l}\text { Physical } \\
\text { environment }\end{array}$ & Domain & Technology & $\begin{array}{l}\text { Data/knowledge } \\
\text { networks }\end{array}$ & Community \\
\hline $\begin{array}{l}\text { Operation } \\
\text { interaction }\end{array}$ & $\begin{array}{l}\text { Determining } \\
\text { interactional } \\
\text { potential of } \\
\text { different areas } \\
\text { of the } \\
\text { CyberPark }\end{array}$ & $\begin{array}{l}\text { Defining a } \\
\text { domain-related } \\
\text { PLE }\end{array}$ & $\begin{array}{l}\text { Promoting digital } \\
\text { and info } \\
\text { competencies; } \\
\text { developing } \\
\text { effective HCI } \\
\text { strategies }\end{array}$ & $\begin{array}{l}\text { Identify data } \\
\text { sources relevant } \\
\text { to PLE }\end{array}$ & $\begin{array}{l}\text { Nurturing } \\
\text { interpersonal } \\
\text { interactional } \\
\text { skills within } \\
\text { groups and } \\
\text { networks }\end{array}$ \\
\hline Wayfinding & $\begin{array}{l}\text { Connecting } \\
\text { specialized } \\
\text { nodes or } \\
\text { information } \\
\text { sources related } \\
\text { to CyberPark }\end{array}$ & $\begin{array}{l}\text { Connecting key } \\
\text { domain info and } \\
\text { knowledge nodes } \\
\text { to the different } \\
\text { aspects of the } \\
\text { CyberPark }\end{array}$ & $\begin{array}{l}\text { Using digital tools } \\
\text { that mediate } \\
\text { learner } \\
\text { connection with } \\
\text { info, knowledge, } \\
\text { resources and } \\
\text { relevant people }\end{array}$ & $\begin{array}{l}\text { Connecting to } \\
\text { relevant data } \\
\text { sources }\end{array}$ & $\begin{array}{l}\text { Connecting } \\
\text { with key } \\
\text { people and } \\
\text { identifying } \\
\text { key features } \\
\text { of mature } \\
\text { identity }\end{array}$ \\
\hline Sensemaking & $\begin{array}{l}\text { Negotiation } \\
\text { and } \\
\text { argumentation } \\
\text { to understand } \\
\text { the different } \\
\text { aspects of } \\
\text { CyberPark }\end{array}$ & $\begin{array}{l}\text { Negotiation and } \\
\text { argumentation of } \\
\text { domain related } \\
\text { knowledge; } \\
\text { developing an } \\
\text { interdisciplinary } \\
\text { knowledge } \\
\text { structure }\end{array}$ & $\begin{array}{l}\text { Linking } \\
\text { technological } \\
\text { affordances to } \\
\text { learning modes }\end{array}$ & $\begin{array}{l}\text { Developing an } \\
\text { organizational } \\
\text { network of data } \\
\text { sources, types } \\
\text { and capturing } \\
\text { devices }\end{array}$ & $\begin{array}{l}\text { Identity } \\
\text { development; } \\
\text { dialogic space } \\
\text { analysis and } \\
\text { expansion }\end{array}$ \\
\hline $\begin{array}{l}\text { Innovation } \\
\text { interaction }\end{array}$ & $\begin{array}{l}\text { Re-design of } \\
\text { Cyberparks to } \\
\text { address citizen } \\
\text { evolving needs }\end{array}$ & $\begin{array}{l}\text { Renovation of } \\
\text { domain } \\
\text { knowledge } \\
\text { relevant to } \\
\text { Cyberparks }\end{array}$ & $\begin{array}{l}\text { Customize tools } \\
\text { to interact in new } \\
\text { ways with the } \\
\text { hybrid } \\
\text { environment }\end{array}$ & $\begin{array}{l}\text { Generating data } \\
\text { through creation } \\
\text { of digital } \\
\text { artefacts }\end{array}$ & $\begin{array}{l}\text { Renovate and } \\
\text { extend users' } \\
\text { social } \\
\text { networks and } \\
\text { digital } \\
\text { footprint }\end{array}$ \\
\hline
\end{tabular}

This final model captures most of the interactional possibilities that can take place in Cyberparks and can be used to design and evaluate smart learning activities. At the basic level operational interactions are possible in all five dimensions to build interaction spaces or PLE that merge knowledge and skill competence in different aspects of Cyberparks. Changing the physical environment into a PLE implies getting to know the interactional potential of each section of the place and linking these to ad hoc learning 
strategies. A smart learning journey, indicating relevant buildings, areas and any associated points of interests facilitates operational interactions in the physical environment. A PLE can be created in a particular domain (history, architecture, engineering, science or humanities) relevant to any aspect of the CyberPark, by identifying resources, support structures involving peer learners, experienced persons or experts, together with learning strategies that can be adopted.

Operational interaction involves connecting learners with different technologies through learner-interface interaction to support their further learning, by connecting with different knowledge and opportunities and by bridging learning across multiple learning and living contexts. Typical actions showing operational interactions with technology include play, download, search, read, view, listen and buy. Also, learners attempt to integrate other social and network-based media into their PLEs and connect with different groups of people and information nodes, to develop a collective distributed technological network. In data rich environments operational interactions enable smartphone users to connect with different data sources after rationalising relevant mobile app interfaces to obtain (and possibly contribute) data related to their learning endeavours. Along the community dimension interpersonal interactional skills have to be nurtured both with contiguous and on-line groups or networks. This develops operational competence with tools used for communication and social networking.

Wayfinding interaction involves finding and connecting the right information and people. Information about different sections of the physical environment are identified and made available for access. People and special interest groups related to the different areas are also identified, organising their means of contact. Learner-content interaction and learner-group interaction are also carried out within any field of knowledge related to the CyberPark, or any part of it, thus elaborating the relevant knowledge web, the learning community and the social networks. This linking and organisational approach is applied to any available or generated data. Typical wayfinding interactions include communicate (chat, rate, comment, message) and share (send, upload, publish).

Sensemaking interaction is a collaborative process that includes information sharing and discussion (Wang et al. 2014). Learners bring together concepts from different domains in a novel way to achieve a coherent comprehension of information and make decisions quickly. Thus, a detailed spatial plan and a global knowledge network serve to integrate the different sections of cyberparks. Knowledge organisation is also carried out in any field consulted, which in turn is linked to the other fields thus creating a final interdisciplinary knowledge structure. With regards to technology, sense making involves linking different digital tools used in various locations in cyberparks, such as QR code systems, augmented reality, geo-tagging and gaming, into a coherent functional system for promoting various modes of learning (Klichowski 2017). Similar patterns are established with regards to data, by creating a bird's eye view of data sources, data types and data capturing devices. Along the community dimension sensemaking interaction manifest itself in the development and sharing of learners' knowledge networks, network identities and social presence. Typical sensemaking interactions involve different modes of facilitation such as recommend, channel, tag, subscribe, filter and mentor. The outcomes of sensemaking interaction are organisational-networked patterns connecting tightly together nodes in geophysical, 
technological, data, social and conceptual (neural) networks which will eventually form the basis for personal contributions in innovation interaction.

Innovation interaction is the deepest form of learner interaction and cognitive engagement. Experienced learners show their knowledge and competence status through contribution, engaging in evaluative and creative activities (Bonanno 2011; 2014). They create (digital) artefacts or elaborate existing ones and share this innovation with others bringing more networking opportunities on the open network where they are both accessible and persistent (Wang et al. 2014). Cyberparks' users can propose new designs or re-designs of the existing space or parts of it, add or modify new knowledge about (aspects of) the cyberpark, or create/modify open educational resources relevant to some particular aspect or theme. New digital technologies or applications can be customised to interact in innovative or more elaborate ways with the physical, virtual and social environments. Cyberparks visitors use available data and generate new data as (multimedia) artefacts to communicate and share their ad hoc experience. New tools or elaboration of existing ones can be used to innovate and extend users' social networks and digital footprint. Thus, key innovation-interaction actions include customises, design, produce, contribute, program, model and evaluate.

This pedagogical model provides the necessary framework to design and assess formal or informal learning in cyberparks. It captures patterns of interactions characterising different learning instances or extension of one's knowledge and social networks. Each square of the grid represents a specific category of interactions that may be used to design focussed learning activities.

\section{Conclusions}

Anderson (2009) uses the tango metaphor: pedagogies and technologies are intertwined in a dance, where the moves of one determine the moves of the other. Cyberparks can serve as emergent hybrid environments where people, spaces, technology and purpose create the movement and rhythm of the dance. Nevertheless, a new approach needs to be adopted, to develop pedagogies for these emerging environments (Gros et al. 2016).

The proposed pedagogical model can serve as a theoretical lens and a practical guide for understanding learner experience in cyberparks. More than serving as a static instrument to fit and analyse learners' experience this model should serve as a signpost in the process of developing adaptive expertise. Gros et al. $(2016 ; 15)$ claim that when "all the components of emerging pedagogies including technology, pedagogy, content and society are evolving, educators need to develop adaptive expertise to understand how these components interplay with and influence their own practices". This model is a proposal to address the continual challenge in developing new pedagogies based on innovative uses of technologies to fulfil the evolving needs and expectations of learners in contexts like Cyberparks. 


\section{References}

Ally, M.: Foundations of educational theory for online learning. In: Anderson, T. (ed.) The Theory and Practice of Online Learning, pp. 15-44. Athabasca University Press, Edmonton (2004)

Anderson, L.W., et al.: A Taxonomy for Learning, Teaching, and Assessing: A Revision of Bloom's Taxonomy of Educational Objectives. Pearson, New York (2000)

Anderson, T.: The dance of technology and pedagogy in selfpaced distance education. Paper presented at the 17th ICDE World Congress, Maastricht (2009)

Anderson, T.: Theories for learning with emerging technologies. In: Veletsianos, G. (ed.) Emerging Technologies in Distance Education, pp. 23-39. Athabasca University Press, Edmonton (2010). https://doi.org/10.15215/aupress/9781771991490.01

Anderson, T., Garrison, D.R.: Learning in a networked world: new roles and responsibilities. In: Gibson, C. (ed.) Distance Learners in Higher Education, pp. 97-112. Atwood Publishing, Madison (1998)

Beetham, H.: Designing for active learning in technology-rich contexts. In: Beetham, H., Sharpe, R. (eds.) Rethinking Pedagogy for a Digital Age: Designing for 21st Century Learning, pp. 49-63. Routledge, New York and London (2013)

Beetham, H., Sharpe, R.: Rethinking Pedagogy for a Digital Age: Designing and Delivering eLearning. Routledge, London and New York (2007)

Blaschke, L.M.: Heutagogy and lifelong learning: a review of heutagogical practice and selfdetermined learning. Int. Rev. Res. Open Distrib. Learn. 13, 56-71 (2012)

Bonanno, P.: A process-oriented pedagogy for ubiquitous learning. In: Kidd, T., Chen, I. (eds.) Ubiquitous Learning: A Survey of Applications, Research, and Trends, pp. 17-35. Information Age Publishing, Charlotte (2011)

Bonanno, P.: Designing learning in social on-line learning environments: a process-oriented approach. In: Mallia, G. (ed.) The Social Classroom: Integrating Social Network Use in Education, pp. 40-61. IGI Global Publishing, Hershey (2014). https://doi.org/10.4018/978-14666-4904-0.ch003

Buchem, I., Perez-Sanagustin, M.: Personal learning environments in smart cities: current approaches and future scenarios. e-Learning Papers 35, 1-14 (2013)

Canning, N.: Playing with heutagogy: exploring strategies to empower mature learners in higher education. J. Further High. Educ. 34, 59-71 (2010). https://doi.org/10.1080/ 03098770903477102

Canning, N., Callan, S.: Heutagogy: spirals of reflection to empower learners in higher education. Reflective Pract. 11, 71-82 (2010). https://doi.org/10.1080/14623940903500069

Chen, L.: A hierarchical model for student and teacher interaction in distance learning. Distance Educ. China 5, 24-28 (2004)

Conole, G.: Designing for Learning in an Open World. Springer, New York (2014)

Cook, J., Lander, R., Flaxton, T.: The zone of possibility in citizen led hybrid cities. Position paper for Workshop on Smart Learning Ecosystems in Smart Regions and Cities. Co-located at EC-TEL, Toledo, Spain (2015)

Downes, S.: Learning networks and connective knowledge. Collective Intell. E-learn. 20, 1-26 (2006). https://doi.org/10.4018/978-1-60566-729-4.ch001

Downes, S.: Learning networks in practice. In: David Ley, E. (ed.) Emerging Technologies for Learning, pp. 19-27. Becta, London (2007)

Dron, J.: Control and Constraint in e-Learning: Choosing When to Choose. Information Science Publishing, Hershey (2007)

Dron, J., Anderson, T.: Teaching Crowds. Edmonton, Athabasca (2014) 
Goodyear, P., Banks, S., Hodgson, V., McConnell, D.: Advances in Research on Networked Learning. Kluwer Academic Publishers, Dordrecht (2004)

Gros, B.: The design of smart educational environments. Smart Learn. Environ. 3, 1-11 (2016). https://doi.org/10.1186/s40561-016-0039-x

Gros, B., Kinshuk, Maina, M.: The Future of Ubiquitous Learning. Lecture Notes in Educational Technology. Springer, New York, Dordrecht, London, Heidelberg (2016)

Hase, S., Kenyon, C.: Heutagogy: a child of complexity theory. Complicity Int. Educ. 4, 111118 (2007)

Hillman, D.C.A., Willis, D.J., Gunawardena, C.N.: Learner-interface interaction in distance education: an extension of contemporary models and strategies for practitioners. Am. J. Distance Educ. 8, 30-42 (1994). https://doi.org/10.1080/08923649409526853

Hirumi, A.: A framework for analyzing, designing, and sequencing planned elearning interactions. Q. Rev. Distance Educ. 3, 141-160 (2002)

Hwang, G.J.: Definition, framework and research issues of smart learning environments - a context-aware ubiquitous learning perspective. Smart Learn. Environ. 1, 1-14 (2014). https:// doi.org/10.1186/s40561-014-0004-5

Isaksson, E., Naeve, A., Lefrère, P., Wild, F.: Towards a reference architecture for smart and personal learning environments. Innovations in Smart Learning. LNET, pp. 79-88. Springer, Singapore (2017). https://doi.org/10.1007/978-981-10-2419-1_13

Klichowski, M.: Learning in CyberParks. A Theoretical and Empirical Study. Adam Mickiewicz University Press, Poznan (2017)

Klichowski, M., Kroliczak, G.: Numbers and functional lateralization: a visual half-field and dichotic listening study in proficient bilinguals. Neuropsychologia 100, 93-109 (2017). https://doi.org/10.1016/j.neuropsychologia.2017.04.019

Klichowski, M., Bonanno, P., Jaskulska, S., Smaniotto Costa, C., de Lange, M., Klauser, F.R.: CyberParks as a new context for Smart Education: theoretical background, assumptions, and pre-service teachers' rating. Am. J. Educ. Res. 3, 1-10 (2015). https://doi.org/10.12691/ education-3-12A-1

Klichowski, M., Patricio, C.: Does the human brain really like ICT tools and being outdoors? a brief overview of the cognitive neuroscience perspective of the cyberparks concept. In: Kenna, T., Zammit, A. (eds.) ICiTy - Enhancing places through technology, pp. 223-239. Lusófona University Press, Lisbon (2017)

Klichowski, M., Smaniotto Costa, C.: How do pre-service teachers rate ICT opportunity for education? a study in perspective of the SCOT theory. Kultura i Edukacja 4, 152-168 (2015). https://doi.org/10.15804/kie.2015.04.09

Latour, B.: Reassembling the Social: An Introduction to Actor-Network-Theory. Oxford University Press, Oxford (2005)

Mayes, T., de Freitas, S.: Review of e-Learning Theories, Frameworks and Models. Joint Information Systems Committee, London (2004)

Moore, M.: Three types of interaction. Am. J. Distance Educ. 3, 1-7 (1989). https://doi.org/10. 1080/08923648909526659

Papert, S.: The Children's Machine: Rethinking School in the Age of the Computer. Basic Books, New York (1993)

Pothier, K., Benguigui, N., Kulpa, R., Chavoix, C.: Multiple object tracking while walking: similarities and differences between young, young-old, and old-old adults. J. Gerontol. Psychol. Sci. Soc. Sci. 70, 840-849 (2014). https://doi.org/10.1093/geronb/gbu047

Sharples, M., et al.: Innovating Pedagogy 2012. The Open University, Milton Keynes (2012)

Siemens, G.: Connectivism: a learning theory for the digital age. Int. J. Instr. Technol. Distance Learn. 2, 3-10 (2005) 
Siemens, G.: Orientation: sensemaking and wayfinding in complex distributed online information environments. University of Aberdeen, Doctoral dissertation (2011)

Takeuchi, N., Mori, T., Suzukamo, Y., Tanaka, N., Izumi, S.I.: Parallel processing of cognitive and physical demands in left and right prefrontal cortices during smartphone use while walking. BMC Neurosci. 17, 1-11 (2016). https://doi.org/10.1186/s12868-016-0244-0

Tan, S.C., Divaharan, S., Tan, L., Cheah, H.M.: Self-directed Learning with ICT: Theory, Practice and Assessment. Ministry of Education, Singapore (2011)

Thomas, V., Ding, W., Mullagh, L., Dunn, N.: Where's wally? in search of citizen perspectives on the smart city. Sustainability 8, 1-13 (2016). https://doi.org/10.3390/su8030207

Wang, Z., Chen, L., Anderson, T.: A framework for interaction and cognitive engagement in connectivist learning contexts. Int. Rev. Res. Open Distrib. Learn. 15, 121-141 (2014)

Yamada, M., Aoyama, T., Okamoto, K., Nagai, K., Tanaka, B., Takemura, T.: Using a smartphone while walking: a measure of dual-tasking ability as a falls risk assessment tool. Age Ageing 40, 516-519 (2011). https://doi.org/10.1093/ageing/afr039

Yuan, P., et al.: Increased brain activation for dual tasking with 70-days head-down bed rest. Front. Syst. Neurosci. 10, 71 (2016). https://doi.org/10.3389/fnsys.2016.00071

Open Access This chapter is licensed under the terms of the Creative Commons Attribution 4.0 International License (http://creativecommons.org/licenses/by/4.0/), which permits use, sharing, adaptation, distribution and reproduction in any medium or format, as long as you give appropriate credit to the original author(s) and the source, provide a link to the Creative Commons license and indicate if changes were made.

The images or other third party material in this chapter are included in the chapter's Creative Commons license, unless indicated otherwise in a credit line to the material. If material is not included in the chapter's Creative Commons license and your intended use is not permitted by statutory regulation or exceeds the permitted use, you will need to obtain permission directly from the copyright holder.

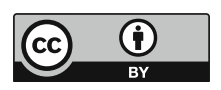

